\title{
Identifikasi Fraksi Fe, Al, dan Si amorf Pada Beberapa Ordo Tanah di Lahan Kering Aceh Besar Dengan Ekstraksi Ammonium Oksalat
}

\section{(Fe, Al, and Si Amorf in Andisol and in the Seulawah Valley Dryland, Aceh Besar District)}

\author{
Ikhwani Fitri ${ }^{1}$, Teti Arabia ${ }^{1}$ Sufardi $^{1 *}$ \\ ${ }^{1}$ Program Studi Ilmu Tanah, Fakultas Pertanian, Universitas Syiah Kuala \\ Corresponding author: sufardi_usk@unsyiah.ac.id
}

\begin{abstract}
Abstrak. Hasil penelitian menunjukkan bahwa kandungan Fe, Al, dan Si amorf pada tanah ordo Andisol di lahan kering Aceh Besar berkisar dari 0,61 - 0,65\%, kandungan Fe amorf tertinggi terdapat pada horizon Ap sebesar $0,65 \%$, sedangkan kandungan terendah terdapat pada horizon $\mathrm{Bw} 0,61 \%$. Untuk kandungan $\mathrm{Al}$ amorf berkisar dari 5,20 - 3,02\%, kandungan Al tertinggi terdapat pada horizon AB sebesar 5,20\% sedangkan kandungan terendah terdapat pada horizon Ap 3,02\%. Untuk kandungan Si amorf berkisar dari 6,81 - 5,92\%, untuk kandungan Si tertinggi terdapat pada horizon Ap sebesar 6,81\%, untuk kandungan terendah terdapat pada horizon $\mathrm{Bw}$ dengan kandungan 5,92\%. Pola distribusi Fe, Al, dan Si amorf pada ordo Andisol di lahan kering Aceh Besar, kandungan Fe pada kedalaman 20 - > $60 \mathrm{~cm}$ relatif stabil, untuk kandungan $\mathrm{Al}$ cenderung naik dari kedalaman 20 - > $60 \mathrm{~cm}$, kemudian untuk pola Si juga terjadi penurunan dari kedalaman $20->60 \mathrm{~cm}$. Untuk kandungan $\mathrm{Fe}, \mathrm{Al}$, dan Si amorf pada ordo Oxisol berkisar dari 0,16 - 9,03\%. Kandungan Fe berkisar dari 0,19$1,65 \%$ kandungan $\mathrm{Fe}$ tertinggi pada Oxisol terdapat pada horizon BA yaitu 1,65\% dan kandungan terendah terdapat pada horizon Bo1 yaitu 0,16\%, untuk kandungan Al berkisar dari 3,48 - 6,44\% kandungan Al tertinggi terdapat pada horizon A yaitu 6,44\% dan kandungan terendah terdapat pada horizon Bo1 yaitu 3,48\%. Pada Si kandungannya berkisar dari 6,37-9,03\%, kandungan Si tertinggi pada Oxisol terdapat pada horizon Bo1 yaitu 9,03\% dan kandungan terendah terdapat pada horizon A yaitu 6,37\%. Pola distribusi Fe, Al, da Si Oxisol di lahan kering Kabupaten Aceh Besar, kandungan Fe terjadi penurunan dari kedalaman $10 \mathrm{~cm}$ sampai kedalaman $>104 \mathrm{~cm}$, dan pada kandungan Al terjadi penurunan dari kedalaman $10 \mathrm{~cm}$ sampai kedalaman $>104 \mathrm{~cm}$. Kemudian untuk kandungan Si kandungannya relatif tetap.
\end{abstract}

Kata Kunci: Fe, Al, dan Si Amorf, lahan kering, Ammonium Oksalat

\begin{abstract}
The results showed that the content of $\mathrm{Fe}, \mathrm{Al}$, and $\mathrm{Si}$ amorphous in the Andisol order in dry land in Aceh Besar ranged from 0.61 to $0.65 \%$, the highest amorphous Fe content was found in the Ap horizon of $0.65 \%$, while the lowest content was at the $\mathrm{Bw}$ horizon of $0.61 \%$. For the amorphous $\mathrm{Al}$ content ranges from $5.20-3.02 \%$, the highest $\mathrm{Al}$ content is in the $\mathrm{AB}$ horizon of $5.20 \%$ while the lowest content is in the Ap 3.02\% horizon. For the amorphous Si content ranges from $6.81-5.92 \%$, for the highest Si content is in the Ap horizon of $6.81 \%$, for the lowest content is found in the Bw horizon with $5.92 \%$ content. Amorphous $\mathrm{Fe}, \mathrm{Al}$, and $\mathrm{Si}$ distribution patterns in the Andisol order in Aceh Besar drylands, Fe content at a depth of $20 \rightarrow 60 \mathrm{~cm}$ is relatively stable, for $\mathrm{Al}$ content tends to rise from a depth of $20 \rightarrow 60 \mathrm{~cm}$, then for the $\mathrm{Si}$ pattern there is also a decrease from a depth of $20->60 \mathrm{~cm}$. For the content of $\mathrm{Fe}, \mathrm{Al}$, and $\mathrm{Si}$ amorphous in the Oxisol order ranges from 0.16 to $9.03 \%$. The Fe content ranges from $0.19-1.65 \%$, the highest Fe content in Oxisol is found on the $\mathrm{BA}$ horizon, which is $1.65 \%$ and the lowest content is on the Bol horizon, $0.16 \%$, for $\mathrm{Al}$ content ranges from $3.48-6,44 \%$ of the highest $\mathrm{Al}$ content is on the A horizon which is $6.44 \%$ and the lowest content is on the Bo1 horizon which is $3.48 \%$. In Si content ranges from $6.37-9.03 \%$, the highest Si content in Oxisol is in the Bo1 horizon which is $9.03 \%$ and the lowest content is in horizon A which is $6.37 \%$. The distribution pattern of $\mathrm{Fe}$, $\mathrm{Al}$, and Si Si Oxisol in Aceh Besar Dryland District, Fe content decreased from a depth of $10 \mathrm{~cm}$ to depth> 104 $\mathrm{cm}$, and in the $\mathrm{Al}$ content decreased from a depth of $10 \mathrm{~cm}$ to a depth of> $104 \mathrm{~cm}$. Then for the womb the content is relatively fixed.
\end{abstract}

Keywords: Fe, Al, dan Si Amorf dryland, Aceh Besar

Jurnal Ilmiah Mahasiswa Pertanian, Volume 4, Nomor 4, November 2019 


\section{PENDAHULUAN}

Lahan kering adalah hamparan lahan yang di dayagunakan tanpa adanya air, baik secara permanen maupun musiman dengan sumber air berupa hujan atau air irigasi (Suwardji, 2003). Definisi yang diberikan oleh (Soil Survey Staff, 2014) lahan kering yaitu hamparan lahan yang tidak pernah digenangi air selama beberap periode dalam waktu setahun. Tipologi lahan ini terdapat di dataran rendah hingga dataran tinggi $(0>700 \mathrm{~m} \mathrm{dpl})$. Dari penjelasan di atas, maka jenis penggunaan lahan yang termasuk dalam kelompok lahan kering mencakup: lahan tadah hujan, tegalan, kebun campuran, perkebunan, hutan, semak, padang rumput, dan padang alang-alang.

Usaha pertanian pada sistem lahan kering umumnya menghadapi banyak kendala karena selain tergantung kepada permasalahan yang berkaitan dengan ketersediaan air, juga ditemukan beberapa permasalahan yang berkaitan dengan karakteristik tanah, permasalahan yang sering ditemukan pada sistem pertanian lahan kering khususnya di iklim tropika basah antara lain tanah bereaksi masam hingga agak masam, kapasitas tukar kation (KTK) tanah dan kejenuhan basa (KB) yang rendah serta rendahnya bahan organik dan ketersediaan unsur hara seperti N, P dan unsur hara lainnya. Namun, permasalahan ini secara khusus agak berbeda antara jenis tanah. Tanah Kambisol Haplik, Kambisol Distrik, dan Lithosol mempunyai KTK dan KB tanah yang lebih rendah dibandingkan dengan nilai KTK dan KB pada Kambisol Eutrik, Andosol Umbrik dan Alluvial Eutrik. Walaupun terjadi perbedaan terhadap beberapa karakteristik tanah, tetapi sebagian besar tanah pada lahan kering mempunyai status kesuburan yang rendah, sehingga perlu penambahan amelioran untuk memperbaiki kualitas tanah (Sufardi et al., 2017).

Sposito (2010), tubuh tanah tersusun atas berbagai macam mineral yang terdiri atas mineral primer dan mineral sekunder, sehingga keragaman komposisi mineral ini di dalam tanah dapat mempengaruhi sifat-sifat fisika, kimia, maupun mineraloginya, sebagai contoh, Andisol merupakan salah satu ordo tanah yang cukup subur tetapi mempunyai tingkat jerapan $\mathrm{P}$ yang tinggi karena didominasi oleh mineral amorf seperti alofan, imogolit, dan ferihidrit dengan permukaan spesifik yang luas dan tanah ini berkembang dari bahan induk abu vulkanik. Oleh karena itu pengolahan Andisol perlu diarahkan untuk mengurangi kemampuan jerapan dan meningkatkan ketersediaan $\mathrm{P}$ antara lain dengan penggunaan asam humat dan asam silikat.

Identifikasi mineral tanah antara lain dapat dilakukan dengan menggunakan metode fisik seperti melalui pengamatan dengan mikroskop, analisis difraksi sinar-x, analisis diferensial termal (DTA) dan/atau dengan menggunakan metode kimia, salah satu metode kimia yang sering dipakai untuk mengidentifikasi fraksi-fraksi mineral tanah adalah metode pelarut selektif, misalnya dengan menggunakan larutan ditionit sitrat untuk mengetahui fraksi $\mathrm{Fe}, \mathrm{Al}$, dan Si bebas (Holmgren, 1967), larutan ammonium oksalat untuk mengathui fraksi $\mathrm{Fe}, \mathrm{Al}$, dan Si amorf (van Reeuwijk, 1992), dan larutan pirofosfat untuk mengetahui fraksi Al dan Fe-humus tanah.

Kabupaten Aceh Besar adalah salah satu wilayah yang mempunyai lahan kering yang masih cukup luas untuk dikembangkan menjadi areal pengembangan pertanian, namun informasi tentang jenis dan komposisi mineral khususnya fraksi $\mathrm{Fe}, \mathrm{Al}$, dan $\mathrm{Si}$ ini masih sangat terbatas. Berdasarkan uraian tersebut penulis tertarik melakukan penelitian yang berjudul "Identifikasi fraksi Al, Fe, Si amorf pada ordo tanah Andisol, dengan menggunakan ekstraksi amonium oksalat. 


\section{METODE PENELITIAN}

Penelitian ini menggunakan metode survai deskriptif yaitu melalui observasi lapangan dan analisis laboratorium untuk pengumpulan data. Survai lapangan dilakukan untuk pengamatan profil tanah/identifkasi ordo (subgroup) tanah dan pengambilan sampel tanah untuk analisis di laboratorium. Penelitian ini dilakukan pada tanah ordo Andisol yang terdapat pada lahan kering di Lembah Seulawah, Kabupaten Aceh Besar dengan letak geografis $05^{\circ} 27^{\prime} 03,2^{\prime \prime}$ LU 95 $43^{\circ} 45,2^{\prime \prime}$ BT. Analisis tanah dan fraksi Fe, Al, dan Si amorf dilakukan di Laboratorium Penelitian Tanah dan Tanaman Fakultas Pertanian Universitas Syiah Kuala. Penelitian ini dilaksanakan pada Juni sampai September 2018. Alat yang digunakan dalam penelitian ini meliputi peralatan untuk identifikasi ordo tanah di lapangan yaitu bor tanah, $\mathrm{pH}$ digital, cangkul, sekop, abney level, buku warna tanah Munsell, meteran, GPS (global positioning system), camera digital, pisau dan kantong sampel serta larutan kimia $\mathrm{H}_{2} \mathrm{O}_{2} 30 \%$ dan $\mathrm{HCl} 10 \%$. Untuk pengamatan, pengukuran dan analisis laboratorium digunakan beberapa peralatan yaitu timbangan analitik empat digit, botol kocok, pipet digital, pipet volumetrik, $\mathrm{pH}$ meter, shaker, centrifus, homogenizer, dan AAS (atomic absorption spectrophotometer) Bahan penelitian yaitu asam oksalat sebanyak 10,8 gram dan ammonium oksalat sebanyak 16,2 gram.

\section{Pengamatan Profil Tanah}

Profil tanah dibuat dengan cara membuka tebing bukit yang telah tersingkap solumnya dan selanjutnya dilakukan pembersihan dinding tebing sehingga tampak profilnya dari lapisan atas hingga sampai terdapat lapisan bahan induk. Profil tanah yang telah dibuka selanjutnya diamati sifat-sifat morfologi yang meliputi batas horizon, simbol/nama dan ketebalan tiap lapisan horizon, serta sifat-sifat fisika tanah seperti warna tanah, tekstur, struktur, konsistensi, dan ciri khusus seperti fraksi kasar, kongkresi, dan lain-lain yang mungkin ditemukan pada saat pengamatan. Pengamatan sifat-sifat morfologi tanah dan penentuan subgroup (ordo) tanah didasarkan pada panduan pengamatan tanah lapangan (Soil Survey Staff, 2014). Data hasil pengamatan dicatat pada kartu pengamatan dan bersamaan dengan itu juga dilakukan pengumpulan/pengukuran data tentang keadaan lingkungan lahan seperti cuaca, kelerengan, vegetasi dan penggunaan lahan berdasarkan visual, pengukuran topografi menggunakan Abney level dan pengukuran ketinggian tempat dengan GPS. Pengeboran tanah dilakukan pada setiap titik pengamatan untuk memverifikasi morfologi tanah dan ketebalan solumnya. Pengambilan sampel tanah pada setiap profil dilakukan dengan mengambil tanah menurut horizon yang telah ditentukan dari masing-masing jenis (subgrup) tanah. Sampel-sampel tersebut dimasukkan kedalam kantong plastik berukuran $1 \mathrm{~kg}$ yang telah diberi kode horizon untuk dianalisis di laboratorium.

Untuk keperluan analisis di laboratorium, sampel-sampel tanah diambil pada setiap lapisan horizon sesuai dengan morfologi ordo tanah yang dipilih pada saat survai di lapangan yaitu tanah ordo Andisol (Eutric Hydrudand)

\section{Analisis Tanah di Laboratroium}

Persiapan sampel dan analisis tanah rutin sampel tanah yang telah diambil di lapangan sebelum dianalisis di laboratorium dikering-anginkan selama 1 minggu. Kemudian sampel tanah tersebut ditumbuk dan diayak menggunakan ayakan $2 \mathrm{~mm}$ dan 0,5 $\mathrm{mm}$. Tanah lolos 
saringan $2 \mathrm{~mm}$ digunakan untuk analisis tekstur, sedangkan tanah ukuran $<0,5 \mathrm{~mm}$ digunakan untuk analisis kimia tanah ( $\mathrm{Al}, \mathrm{Fe}$, dan $\mathrm{Si}$ Amorf). Analisis fraksi Fe, Al, dan Si-amorf dilakukan pada setiap sampel tanah yang mewakili horizon dari setiap profil tanah yang dikaji. Analisis fraksi-fraksi tersebut dilakukan dengan menggunakan larutan asam amonium oksalat.

Penyiapan bahan ekstraksi:

1. Larutan ekstraksi ammonium oksalat $\left(\left(\mathrm{COONH}_{4}\right)_{2} \cdot \mathrm{H}_{2} \mathrm{O}\right)$ di timbang sebanyak 16,2 gram dan asam oksalat $\left.(\mathrm{COOH})_{2} .2 \mathrm{H}_{2} \mathrm{O}\right)$ ditimbang sebanyak 10,8 gram.

2. Prosedur ekstraksi

$1000 \mathrm{mg}$ sampel tanah di masukkan ke dalam botol $100 \mathrm{ml}$, lalu di tambahkan $60 \mathrm{ml}$ ekstak menggunakan pipet gondok dan di kocok selama 12 jam dengan mesin pengocok. Selanjutnaya di ambil $25 \mathrm{ml}$ ekstrakkan menggunakan pipet volumetric dan dimasukkan kedalalam tabung reaksi untuk di centrifus selama 15 menit pada $2500 \mathrm{rpm}$, lalu disaring dan disimpan menggunakan botol yang gelap. Selanjutnya diambil supernatant yang telah di sentrifus untuk pengukuran $\mathrm{Fe} \mathrm{Al}$ dan Si kemudian di ukur menggunakan (AAS) dengan panjang gelombang Fe adalah 248,3 nm, untuk Al 309,3 nm, dan Si 251,6 nm. Setelah didapatkan hasil kandungan $\mathrm{Al}, \mathrm{Fe}$, dan $\mathrm{Si}$ amorf dari pengukuran AAS selanjutkan akan dilakukan perhitungan di Microsoft Excel.

3. Perhitungan

Perhitungan untuk Fe, Al, dan Si menggunakan rumus sebagai berikut:

$$
\text { Fe, Al, dan Si }(\%)=\frac{(\boldsymbol{C}-\boldsymbol{B}) \times \boldsymbol{D} \times\left(\mathbf{6 0}+\left(\boldsymbol{W}-\left(\frac{W}{m c f}\right) \times \boldsymbol{m c f}\right.\right.}{W \times \mathbf{1 0}}
$$

Keterangan:

$\mathrm{C} \quad=$ Konsentrasi $\mathrm{Fe}, \mathrm{Al}$, dan Si pada sampel $\left(\mathrm{mg} \mathrm{L}^{-1}\right)$

$\mathrm{B}=$ Konsentrasi $\mathrm{Fe}, \mathrm{Al}$, dan Si pada blanko $\left(\mathrm{mg} \mathrm{L}^{-1}\right)$

$\mathrm{D}=$ Faktor pengencer

mcf $=$ Faktor koreksi kelembaban

$\mathrm{W}=$ Berat sampel $(\mathrm{mg})$

$50=$ Faktor koreksi

\section{HASIL DAN PEMBAHASAN}

\section{Deskripsi dan Karakteristik Tanah}

Hasil identifikasi sifat-sifat morfologi dan ciri horizon penciri pada Andisol dan Oxisol di Kabupaten Aceh Besar dapat dilihat pada Tabel 1. Berdasarkan hasil pengamatan profil di lapangan dan analisis di laboratorium menunjukkan bahwa ordo Andisol tersusun atas empat horizon yaitu Ap, AB, Bw, dan BC di Kecamatan Lembah Seulawah dengan ketebalan solum $>60 \mathrm{~cm}$, dan Oxisol tersusun atas lima horizon yaitu A, AB, BA, Bo1, Bo2 dengan ketebalan solum $>104 \mathrm{~cm}$. 
Tabel 1. Klasifikasi subgrup tanah menurut Soil Survey Staff (2014) dari empat ordo tanah di lahan kering Kabupaten Aceh Besar

\begin{tabular}{|c|c|c|c|c|c|c|}
\hline Ordo & & Subgrup & Tekstur & Susunan Horizon & $\begin{array}{l}\text { Rezim } \\
\text { Tanah }\end{array}$ & $\begin{array}{l}\text { Mineral } \\
\text { dominan }\end{array}$ \\
\hline $\begin{array}{l}\text { Andisol } \\
\text { (Kecamatan } \\
\text { Seulawah) }\end{array}$ & Lembah & $\begin{array}{l}\text { Eutric } \\
\text { Hydrudand }\end{array}$ & Sedang & $\mathrm{Ap}, \mathrm{AB}, \mathrm{Bw}, \mathrm{BC}$ & Udic, IHP & Campuran \\
\hline $\begin{array}{l}\text { Inceptisol } \\
\text { (Desa Datagaseu) }\end{array}$ & & $\begin{array}{l}\text { Oxyaquic } \\
\text { Dystrudept }\end{array}$ & Berlempung & $\begin{array}{l}\mathrm{Ap}, \mathrm{AB}, \mathrm{BA}, \\
\mathrm{BC}, \mathrm{C}_{1}, \mathrm{C}_{2}\end{array}$ & Udic, IHP & Campuran \\
\hline $\begin{array}{l}\text { (Oxisol Desa } \\
\text { Mulia) }\end{array}$ & Suka & $\begin{array}{l}\text { Plinthic } \\
\text { Kandiudox }\end{array}$ & Halus & $\begin{array}{l}\mathrm{A}, \mathrm{AB}, \mathrm{BA}, \mathrm{Bo}_{1}, \\
\mathrm{Bo}_{2}\end{array}$ & Udic, IHP & Campuran \\
\hline
\end{tabular}

Keterangan: IHP = isohyperthermic

\section{Kandungan Al, Fe, serta Si Amorf}

Tabel 2. Kandungan Fe, Al, serta Si Amorf pada Beberapa Ordo Tanah

\begin{tabular}{llcccc}
\hline $\begin{array}{l}\text { Jenis } \\
\text { Tanah }\end{array}$ & $\begin{array}{c}\text { Simbol } \\
\text { Horizon }\end{array}$ & $\begin{array}{c}\text { Kedalaman } \\
(\mathrm{cm})\end{array}$ & \multicolumn{2}{c}{$\mathrm{Fe}, \mathrm{Al} \& \mathrm{Si}$ Amorf (Oksalat) } \\
\cline { 3 - 6 } & & & $\mathrm{Fe}_{\mathrm{o}}$ & $\begin{array}{c}\mathrm{Al}_{\mathrm{o}} \\
(\%)\end{array}$ & $\mathrm{Si}_{\mathrm{o}}$ \\
\hline Andisol & $\mathrm{Ap}$ & $0-20$ & 0,65 & 3,02 & 6,81 \\
& $\mathrm{AB}$ & $20-38$ & 0,63 & 5,20 & 6,03 \\
& $\mathrm{BW}$ & $38-60$ & 0,61 & 5,20 & 5,92 \\
& $\mathrm{BC}$ & $>60$ & 0,65 & 4,57 & 6,37 \\
& & & & & \\
Inceptisol & $\mathrm{Ap}$ & $0-15$ & 0,32 & 2,08 & 1,37 \\
& $\mathrm{AB}$ & $15-26$ & 0,17 & 1,46 & 0,48 \\
& $\mathrm{BA}$ & $26-45$ & 0,22 & 2,08 & 0,81 \\
& $\mathrm{BW}$ & $45-70$ & 0,10 & 2,08 & 2,25 \\
& $\mathrm{BC}$ & $70-100$ & 0,09 & 1,93 & 2,59 \\
& $\mathrm{C}_{1}$ & $>100$ & 0,05 & 5,35 & 3,25 \\
& $\mathrm{C}_{2}$ & $>105$ & 0,16 & 4,11 & 1,70 \\
& & & & & \\
Oxisol & $\mathrm{A}$ & $0-10$ & 0,36 & 6,44 & 6,37 \\
& $\mathrm{AB}$ & $10-35$ & 0,23 & 3,95 & 7,70 \\
& $\mathrm{BA}$ & $35-69$ & 1,65 & 4,73 & 7,81 \\
& $\mathrm{Bo}$ & $69-104$ & 0,16 & 3,48 & 9,03 \\
& $\mathrm{Bo}_{2}$ & $>104$ & 0,19 & 4,26 & 7,72 \\
\hline
\end{tabular}

Keterangan : $\mathrm{Fe}_{\mathrm{o}}=\mathrm{Fe}$ oksalat, $\mathrm{Al}_{\mathrm{o}}=\mathrm{Al}$ oksalat, $\mathrm{Si}_{\mathrm{o}}=\mathrm{Si}$ oksalat

Sumber : Hasil analisis laboratorium (data diolah, 2018)

Pada Andisol Lembah Seulawah kandungan Fe-amorf $\left(\mathrm{Fe}_{\mathrm{o}}\right)$ terdapat empat lapisan horizon terdiri dari Ap, $\mathrm{AB}, \mathrm{Bw}$, dan $\mathrm{BC}$ yang berkisar dari 0,61\% sampai 0,65\% (Gambar 2). Pada lapisan Ap dan AB kandungan berkisar dari 0,65\% sampai dengan 0,63\%, untuk nilai $\mathrm{Bw}$ dan $\mathrm{BC}$ kandungannya berkisar dari $0,61 \%$ sampai $0,65 \%$. Kandungan Fe-amorf pada 
Andisol yang paling tinggi terdapat pada horizon Ap dan horizon $\mathrm{BC}$ dengan kandungan yang sama yaitu $0,65 \%$ (dapat dilihat pada Tabel 3 ). Kandungan yang paling rendah terdapat pada horizon Bw yaitu 0,61\%. Menurut Soil Survey Staff (2003) tanah yang terkandung Al dan Fe yang diekstrak dengan ammonium oksalat mempunyai kandungan amorf yang tinggi dan didominasi oleh jenis mineral alofan. Pedon EY 151 dan KR 139 dengan kandungan $\mathrm{Al}+1 / 2$ Fe yang menunjukkan adanya bahan amorf yang tinggi dan relatif meningkat pada kedalaman tanah dan menunjukkan bahwa kandungan amorf pada tanah ini berasal dari pelapukan bahan induknya. Pada pedon tanah lainya nilai $\mathrm{Al}+1 / 2 \mathrm{Fe}$ mengecil kearah bahan induknya, ini menunjukkan bahwa adanya abu volkan di dalam horizon-horizonnya.

Pada Andisol Lembah Seulawah kandungan Al-amorf $\left(\mathrm{Al}_{\mathrm{o}}\right)$ terdapat empat lapisan horizon yaitu Ap, AB, BW, BC berkisar dari 3,02\% sampai 5,20\%. Kandungan Al-amorf pada horizon Ap yaitu 3,02\%, kemudian pada lapisan $\mathrm{AB}$ kandungannya terjadi kenaikan menjadi 5,20\%, dan begitu pun pada lapisan BW kandungannya tetap sama yaitu 5,20\% tidak terjadi kenaikan maupun penurunan. Dan pada lapisan BC kandungannya terjadi penurunan menjadi 4,57\%. Kandungan Al-amorf pada Andisol yang paling tinggi terdapat pada horizon $\mathrm{AB}$ dan $\mathrm{Bw}$ dengan kandungan yang sama yaitu 5,20\%, kemudian kandungan Al-amorf yang paling rendah terdapat pada horizon Ap atau horizon paling atas yaitu 3,02\%.

Kandungan Si Andisol Lembah Seulawah terdapat empat lapisan horizon yaitu Ap, AB, $\mathrm{Bw}$, dan $\mathrm{BC}$ yang nilai kandungan berkisar dari 5,92\% sampai 6,81\% (Gambar 1). Pada Horizon Ap kandungannya yaitu sebesar 6,81\%, pada horizon AB dan horizon $\mathrm{Bw}$ kandungannya terjadi penurunan sehingga menjadi 5,92\% (dapat dilihat pada Tabel 2). Pada horizon BC kandungannya terjadi kenaikan yaitu menjadi 6,37\%. Pada Andisol kandungan yang paling tinggi terdapat pada horizon Ap yaitu 6,81\%, dan kandungan yang paling rendah terdapat pada horizon $\mathrm{AB}$ dengan kandungan yaitu 5,92\%.

\section{Fe, Al, dan Si Inceptisol}

Kandungan $\mathrm{Fe}$-amorf $\left(\mathrm{Fe}_{\mathrm{o}}\right)$ pada Inceptisol Seulimum terdapat pada tujuh lapisan horizon yaitu $\mathrm{Ap}, \mathrm{AB}, \mathrm{BA}, \mathrm{BW}, \mathrm{BC}, \mathrm{C}_{1}$, dan $\mathrm{C}_{2}$. Kandungannya berkisar dari 0,05 sampai 0,32\%. Pada lapisan Ap kandungan Fe-amorf yaitu 0,32\%, kemudian pada lapisan AB kandungan $\mathrm{Fe}$-amorf terjadi penurunan menjadi $0,17 \%$, dan pada lapisan $\mathrm{BA}$ terjadi kenaikan menjadi $0,22 \%$. Pada lapisan $\mathrm{BW}, \mathrm{BC}$ dan $\mathrm{C}_{1}$ terjadi penurunan menjadi 0,05\% (dapat dilihat pada Tabel 2). Kandungan Fe-amorf pada lapisan $C_{2}$ terjadi kenaikan yaitu menjadi $0.16 \%$. Pada Inceptisol kandungan yang paling tinggi terdapat pada lapisan Ap dengan kandungan sebesar $0,32 \%$, dan kandungan yang terendah terdapat pada horizon $\mathrm{C}_{1}$ yaitu $0,05 \%$.

Kandungan $\mathrm{Al}$-amorf $\left(\mathrm{Al}_{\mathrm{o}}\right)$ pada Inceptisol Seulimum terdapat pada tujuh lapisan horizon yaitu $\mathrm{Ap}, \mathrm{AB}, \mathrm{BA}, \mathrm{Bw}, \mathrm{BC}, \mathrm{C}_{1}$ dan $\mathrm{C}_{2}$ yang nilainya berkisar dari 1,46 sampai 5,35\%. Pada lapisan Ap kandungannya yaitu 2,08\%, pada horizon AB kandungannya terjadi penurunan yaitu 1,46\%, kemudian pada horizon BA kandungannya yaitu 2,08\%, dan horizon $\mathrm{BW}$ dan horizon $\mathrm{BW}$ kandungannya sama yaitu 2,08\%, pada horizon $\mathrm{BC}$ kandungannya terjadi penurunan yaitu $1,93 \%$, pada horizon $\mathrm{C}_{1}$ dan $\mathrm{C}_{2}$ kandungan Al-amorf terjadi kenaikan yaitu menjadi $4,11 \%$. Kandungan Al-amorf pada Inceptisol yang paling tinggi terdapat pada horizon $\mathrm{C}_{1}$ yaitu $5,35 \%$, kemudian kandungan $\mathrm{Al}$-amorf paling rendah terdapat pada horizon $\mathrm{AB}$ dengan kandungan yaitu $1,46 \%$.

Kandungan Si-amorf $\left(\mathrm{Si}_{\mathrm{o}}\right)$ pada Inceptisol Seulimum terdapat tujuh lapisan horizon yaitu $\mathrm{Ap}, \mathrm{AB}, \mathrm{BA}, \mathrm{Bw}, \mathrm{C}_{1}$, dan $\mathrm{C}_{2}$ yang kandungannya berkisar dari 0,48 sampai 3,25\%. Pada horizon Ap kandungan yaitu 1,37\%, kemudian pada horizon AB dan horizon BA 
kandungannya terjadi penurunan menjadi $0,81 \%$ (dapat dilihat pada Tabel 2). Kemudian pada horizon $\mathrm{Bw}$. $\mathrm{BC}$ dan horizon $\mathrm{C}_{1}$ kandungannya terjadi kenaikan yaitu menjadi 3,25\%. Pada horizon $\mathrm{C}_{2}$ kandungannya kembali terjadi penurunan yaitu menjadi $1,70 \%$. Pada Si-amorf kandungan yang paling tinggi terdapat pada horizon $\mathrm{C}_{1}$ dengan kandungan yaitu sebesar $3,25 \%$, dan kandungan yang paling rendah terdapat pada horizon $\mathrm{AB}$ dengan kandungan $0,48 \%$.

\section{Fe, Al, dan Si Oxisol}

Pada ordo Oxisol Lembah Seulawah terdapat pada lima lapisan horizon yaitu A, AB, $\mathrm{BA}, \mathrm{B}_{\mathrm{O} 1}$, dan $\mathrm{B}_{\mathrm{O} 2}$ yang kandunganya berkisar dari 0,16 sampai 1,65\% (Gambar 2). Pada lapisan A kandungannya yaitu $0,36 \%$, kemudian pada lapisan AB terjadi penurunan kandungan yaitu $0,23 \%$, pada lapisan BA terjadi kenaikan dengan kandungan yaitu 1,65\%, kemudian pada lapisan $\mathrm{Bo}_{1}$ kembali terjadi penurunan yaitu menjadi $0,16 \%$, dan pada horizon $\mathrm{Bt}_{2}$ kandunganya kembali terjadi kenaikan yang tidak jauh dari lapisan Bo ${ }_{1}$ yaitu 0,19\% (dapat dilihat pada Tabel 2). Pada Oxisol kandungan Fe-amorf yang paling tinggi terdapat pada horizon BA sebesar $1,65 \%$, kemudian kandungan yang paling rendah terdapat pada horizon $\mathrm{Bo}_{1} 0,16 \%$.

Hasil penelitian Arabia (2009) di Daerah Bogor pada tanah Latosol Merah (Oxisol) menunjukkan bahwa kandungan Fe mengalami penurunan seiring dengan bertambahnya kedalaman tanah, kandungannya berkisar dari 0,96 sampai 1,71\%. Pada lapisan atas kandungannya yaitu $1,25 \%$, dan mengalami kenaikan pada lapisan selanjutnya dengan kandungan yaitu $1,71 \%$, dan kemudian terjadi penurunan menjadi $1,08 \%$, dan pada horizon selanjutnya juga kembali terjadi penurunan menjadi 0,96\%.

Oxisol Lembah Seulawah terdapat pada lima lapisan horizon yang terdiri dari $\mathrm{A}, \mathrm{AB}$, $\mathrm{BA}, \mathrm{B}_{\mathrm{O} 1}$ dan $\mathrm{B}_{\mathrm{O} 2}$, kandungannya berkisar dari 3,48 sampai 6,44\% (Gambar 2). Kandungan $\mathrm{Al}$ amorf pada horizon A yaitu sebesar $6,44 \%$, kemudian pada horison $\mathrm{AB}$ nilai kandungannya terjadi penurunan yaitu menjadi 3,95\%, pada horison BA kandungannya terjadi keniakan yaitu 4,73\%, kemudian pada horison $\mathrm{Bo}_{1}$ kandungannya kembali terjadi penurunan yaitu menjadi 3,48\%, pada horizon $\mathrm{Bo}_{2}$ kandungannya kembali terjadi kenaikan menjadi 4,26\%. Kandungan Al-amorf pada Oxisol yang paling tinggi terdapat pada horizon A dengan nilai yaitu $6,44 \%$, dan nilai yang paling rendah terdapat pada horizon BA yaitu dengan nilai 3,48\%.

Hasil penelitian Arabia (2009) pada tanah Latosol Merah (Oxisol) menunjukkan bahwa kandungan Al menunjukkan bahwa kandungan Al terjadi kenaikan seiring dengan bertambahnya kedalaman tanah, kandungannya berkisar dari $0,40 \%$ sampai $0,53 \%$. Pada lapisan atas kandungannya yaitu $0,40 \%$ kemudian terjadi kenaikan pada lapisan selanjutnya yaitu menjadi $0,46 \%$, dan sampai $0,52 \%$.

Kandungan Si-amorf $\left(\mathrm{Si}_{\mathrm{o}}\right)$ pada Oxisol Lembah Seulawah terdapat pada lima horizon yaitu $\mathrm{A}, \mathrm{AB}, \mathrm{BA}, \mathrm{B}_{\mathrm{O} 1}$, dan $\mathrm{B}_{\mathrm{O} 2}$, kandungannya berkisar dari 6,37 sampai 9,03\% (Gambar 2). Pada Horizon A kandungannya yaitu 6,37\%. Pada horizon AB, BA dan $\mathrm{Bo}_{1}$ kandungannya terjadi kenaikan sehingga menjadi 9,03\% (dapat dilihat pada Tabel 2). Kemudian pada horizon $\mathrm{Bo}_{2}$ kandungannya terjadi penurunan yaitu menjadi 7,72\%. Pada Oxisol kandungan $\mathrm{Si}$-amorf yang paling tinggi terdapat pada horizon $\mathrm{Bo}_{2}$ yaitu sebesar 9,03\%, dan kandungan yang paling rendah terdapa pada horizon A yaitu dengan nilai 6,37\%.

Penelitian Apriani (2018) pada tanah ordo Inceptisol di Cucum Kabupaten Aceh Besar ini memiliki kandungan mineral tertinggi jenis gibsit pada horizon Ap dengan intensitas yang dihasilkan yaitu 954. Disamping itu, tanah ordo Inceptisol di Cucum di dominasi oleh mineral 
paligorskit dan gibsit. Poligorskit termasuk mineral kaya silika, strukturnya mirip mineral tipe 2:1. Pada kelompok ini, mempunyai kelebihan muatan positif (+) sehingga kapasitas tukar anion (KTA) menjadi tinggi dan kapasitas tukar kation (KTK) sedang.

\section{Distribusi Fe, Al, dan Si Amorf pada beberapa ordo tanah}

Distribusi Fe, Al, dan Si-amorf pada Andisol Lembah Seulawah di lahan kering Aceh Besar dapat dilihat pada Gambar 1. Dari Gambar menunjukkan bahwa secara umum kandungan Fe-amorf pada Andisol lebih rendah di bandingkan dengan kandungan Al dan Siamorf. Kandungan Fe-amorf mengalami penurunan dari kedalaan $20 \mathrm{~cm}$ sampai dengan 60 $\mathrm{cm}$, kemudian terjadi kenaikan pada kedalaman $>60 \mathrm{~cm}$. Pada Al-amorf kandungannya terjadi kenaikan dari kedalaman $38 \mathrm{~cm}$ sampai dengan kedalaman $60 \mathrm{~cm}$ dan terjadi penurunan pada kedalaman $>60 \mathrm{~cm}$. Untuk kandungan Si-amorf terjadi penurunan dari kedalaman $20 \mathrm{~cm}$ sampai kedalaman $>60 \mathrm{~cm}$ seiring dengan bertambahnya kedalaman tanah.

Pola distribusi Fe, Al, dan Si amrorf pada tanah ordo Andisol di lahan kering Kabupaten Aceh Besar, kandungan Fe pada kedalaman 20 sampai $>60 \mathrm{~cm}$ relatif stabil, dan untuk kandungan $\mathrm{Al}$ cenderung naik dari kedalaman 20 sampai $>60 \mathrm{~cm}$, kemudian untuk pola kandungan Si juga terjadi penurunan pada kedalaman $20 \mathrm{~cm}$ sampai $>60 \mathrm{~cm}$.

Menurut Soil Survey Staff (2014), Andisol adalah tanah yang berkembang dari abu vulkanik letusan gunung berapi. Penyebaran tanah Andisol di Indonesia sangat luas dan hampir 5 juta hektar atau 2,9\% dari seluruh luas daratan Indonesia. Andisol mempunyai sifat yang sering disebut dengan tanah andik, yaitu memiliki kandungan bahan organik lebih dari 23\% dan banyak terdapat kandungan amorf yaitu alofan, ferihidrit, imogilit, dan senyawa humus yang sangat tinggi pada Andisol.

Pada pola distribusi Fe, Al, da Si Inceptisol di lahan kering Kabupaten Aceh Besar kandungan Fe cenderung menurun pada kedalaman $15 \mathrm{~cm}$ sampai kedalaman $>105 \mathrm{~cm}$, dan pada kandungan Al cenderung naik pada kedalaman $26 \mathrm{~cm}$ sampai kedalaman $>105 \mathrm{~cm}$, kemudian kandungan Si terjadi fluktasi (meningkat) pada kedalaman $15 \mathrm{~cm}$ sampai kedalaman $>100$ $\mathrm{cm}$.

Distribusi Fe, Al, dan Si-amorf pada ordo Inceptisol Seulimum di lahan kering Aceh Besar dapat dilihat pada Gambar 2. Dari Gambar 2 menunjukkan bahwa pola distribusi Feamorf kandungannya semakin menurun pada kedalaman $15 \mathrm{~cm}$ sampai dengan kedalaman > $105 \mathrm{~cm}$ seiring dengan bertambahnya kedalaman tanah. Kandungan Al-amorf pada ordo Inceptisol juga terjadi penurunan dari kedalaman $15 \mathrm{~cm}$ sampai dengan kedalaman $100 \mathrm{~cm}$, kemudian terjadi peningkatan pada kedalaman $>105 \mathrm{~cm}$. Sementara itu kandungan Si amorf pada ordo Inceptisol terjadi penurunan dari kedalaman $26 \mathrm{~cm}$ samapi kedalaman $45 \mathrm{~cm}$, dan terjadi kenaikan pada kedalaman $70 \mathrm{~cm}$ sampai $105 \mathrm{~cm}$.

Hasil penelitian Arabia (2009) di tanah Latosol Coklat Kekuningan (Inceptisol) menunjukkan bahwa kandungan $\mathrm{Fe}$ terajdi peningkatan seiring dengan bertambahnya kedalaman tanah, pada kedalaman $12 \mathrm{~cm}$ sampai $200 \mathrm{~cm}$ terjadi peningkatan dengan kandungan berkisar dari $0,80 \%$ sampai $0,87 \%$. Kemudian untuk kandungan Al juga terjadi peningkatan pada kedalaman $12 \mathrm{~cm}$ sampai $200 \mathrm{~cm}$ dengan kandungan berkisar dari 0,81\% sampai $0,97 \%$.

Inceptisol merupakan tanah muda dan belum berkembang lanjut, mempunyai horizon kambik, yaitu horizon alterasi atau horizon yang mengalami perubahan tahap awal yang mempunyai ciri yaitu terjadinya perkembangan struktur atau perubahan warna tanah pada tahapan awal, perubahan tersebut terjadi secara kimia, dan merupakan hasil gabungan dari 
dua atau lebih proses tersebut (Soil Survey Staff, 2014) peningkatan pada kedalaman $12 \mathrm{~cm}$ sampai $200 \mathrm{~cm}$ dengan kandungan berkisar dari 0,81\% sampai 0,97\%.

Inceptisol merupakan tanah muda dan belum berkembang lanjut, mempunyai horizon kambik, yaitu horizon alterasi atau horizon yang mengalami perubahan tahap awal yang mempunyai ciri yaitu terjadinya perkembangan struktur atau perubahan warna tanah pada tahapan awal, perubahan tersebut terjadi secara kimia, dan merupakan hasil gabungan dari dua atau lebih proses tersebut (Soil Survey Staff, 2014).

Ciri khas Inceptisol ini adalah tanahnya mulai berkembang, kemudian mempunyai epipedon Ochric (pucat), dan masih sedikit menunjukkan adanya eluviasi dan iluviasi. Inceptisol adalah jenis tanah yang mempuyai horizon alterisasi, yang telah tidak ada terkandung besi dan aluminium tetapi mengandung mineral-mineral mudah lapuk, (Sevindrajuta, 2012).

Distribusi Fe, Al, dan Si-amorf pada Oxisol Lembah Seulawah di lahan Kering Aceh Besar dapat dilihat pada Gambar 3. Dari Gambar 3 menunjukkan kandungan Fe-amorf terjadi penurunan pada kedalaman $10 \mathrm{~cm}$, kemudian terjadi kenaikan pada kedalaman $35 \mathrm{~cm}$, kemudian kembali terjadi penurunan dari kedalaman $69 \mathrm{~cm}$ sampai dengan kedalaman 104 $\mathrm{cm}$. Kemudian pada Al-amorf terjadi penurunan dari kedalaman $10 \mathrm{~cm}$ sampai dengan kedalaman $>104 \mathrm{~cm}$ seiring dengan bertamabahnya kedalaman tanah. Pada Si-amorf terjadi penurunan dari kedalaman $10 \mathrm{~cm}$ sampai dengan kedalaman $35 \mathrm{~cm}$, kemudian terjadi kenaikan pada kedalaman $69 \mathrm{~cm}$, dan kembali terjadi penurunan dari kedalman 104 sampai $<104 \mathrm{~cm}$.

Pada pola distribusi Fe, Al, da Si Oxisol di lahan kering Kabupaten Aceh Besar, kandungan Fe terjadi penurunan dari kedalaman $10 \mathrm{~cm}$ sampai kedalman $>104 \mathrm{~cm}$, dan pada kandungan Al terjadi penurunan dari kedalaman $10 \mathrm{~cm}$ sampai kedalaman $>104 \mathrm{~cm}$. Kemudian untuk kandungan Si kandungannya relatif tetap.

Hasil penelitian Arabia (2009) pada tanah Latosol Merah (Oxisol) menunjukkan bahwa kandungan $\mathrm{Fe}$, dan $\mathrm{Al}$ menunjukkan bahwa kandungan Fe pada kedalaman $16 \mathrm{~cm}$ sampai 28 mengalami kenaikan, kemudian pada kedalaman $28-50 \mathrm{~cm}$ terjadi penurunan, dan kembali lagi terjadi penurunan pada kedalaman $50-89 \mathrm{~cm}$. Pada kandungan Al kandungannya terus mengalami kenaikan seiring dengan bertambahnya kedalaman tanah yaitu dari kedalalaman $16 \mathrm{~cm}$ sampai dengan kedalaman $89 \mathrm{~cm}$.

Oxisol adalah tanah-tanah yang berasal dari bahan induk volkanik, bersolum dalam, batas-batas horizon baur, konsistensi remah telah mengalami pelapukan lanjut, sangat tercuci, kandungan mineral primer rendah, dan terjadi akumulasi seskuioksida $\left(\mathrm{Fe}_{2} \mathrm{O}_{3}\right)$ dan $\left(\mathrm{Al}_{2} \mathrm{O}_{3}\right)$ akibat pencucian silika. Oxisol merupakan tanah yang mempunyai ciri horizon oksik yang tebal. Pelapukan yang terjadi dalam kurun waktu yang lama menyebabkan terjadinya pelindian basa dan silika, serta terjadinya pembentukan lempung kaolinit. (Hardjowigeno, 2003).

Menurut penelitian Ferdeanty (2018) pada tanah ordo Oxisol didominasi oleh Fe dan Mn pada setiap horizon. Karatan tanah berbentuk bercak yang diakibatkan oleh larutnya beberapa komponen tanah, seperti Fe dan Mn. Warna karatan Fe pada horizon A, AB, BA, $\mathrm{Bo}_{1}$, dan $\mathrm{Bo}_{2}$ adalah merah kekuningan sampai cokelat. Sedangkan warna karatan Mn hanya terdapat pada horizon $\mathrm{BA}, \mathrm{Bo}_{1}$, dan $\mathrm{Bo}_{2}$ yaitu Gley $10 \mathrm{YR}^{7} / 1$ (kelabu terang). 

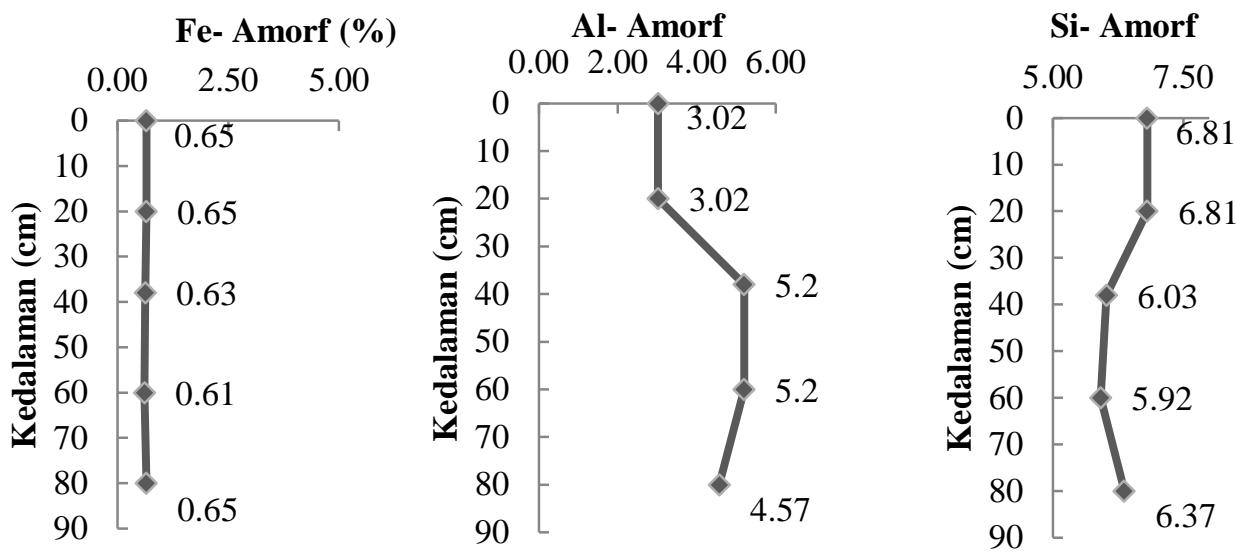

Gambar 1. Distribusi Fe, Al, dan Si pada Ordo Andisol Kecamatan Lembah Seulawah di Lahan Kering Kabupaten Aceh Besar
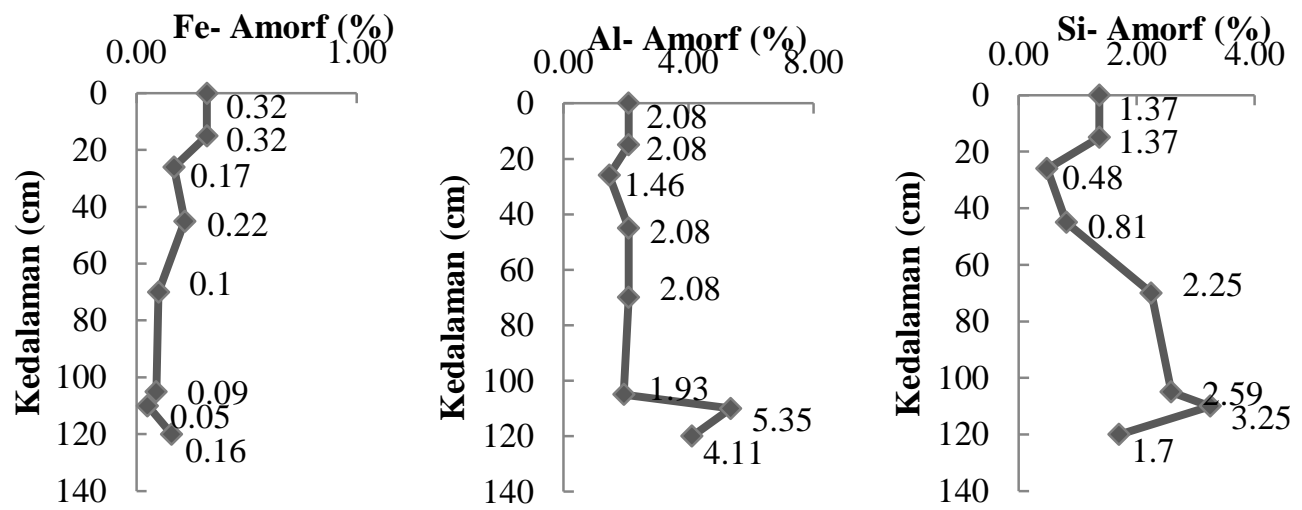

Gambar 2. Distribusi Fe, Al, dan Si pada dari Ordo Inceptisol Desa Datagaseu di Lahan Kering Kabupaten Aceh Besar
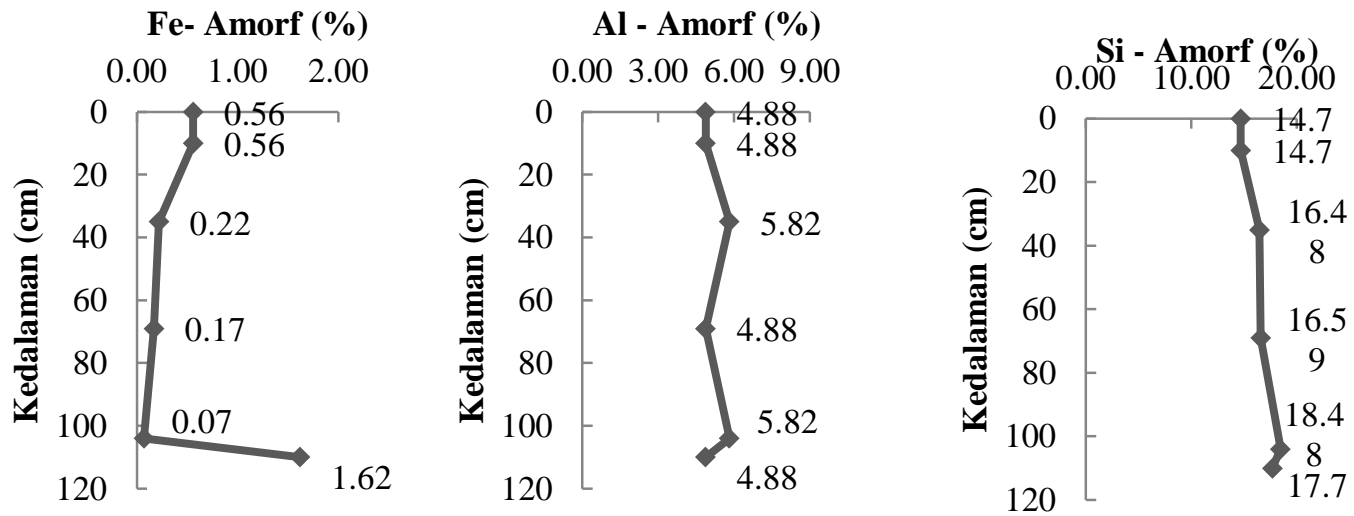

Gambar 3. Distribusi Fe, Al, dan Si pada Ordo Ultisol Desa Jalin di Lahan Kering Kabupaten Aceh Besar 


\section{Kesimpulan}

\section{KESIMPULAN DAN SARAN}

Kandungan $\mathrm{Fe}, \mathrm{Al}$, dan Si amorf pada Andisol tergolong rendah, kandungan Fe tertinngi terdapat pada horizon Ap sebesar 0,65\%, sedangkan kandungan Fe terendah terdapat pada horizon $\mathrm{Bw}$ 0,61\%. Untuk kandungan $\mathrm{Al}$ tertinngi terdapat pada horizon $\mathrm{AB} 5,20 \%$, dan kandungan Si tertinggi terdapat pada horizon Ap 6,81\%. Kandungan $\mathrm{Fe}, \mathrm{Al}$, dan Si amorf pada Oxisol bervariasi dari rendah sampai tinggi, kandungan Fe oxisol tertinggi terdapat pada horizon BA 1,65\%, dan kandunga terendah terdapat pada Bo1 0,16\%. Untuk kandungan Al tertinggi terdapat pada horizon A 6,44\% dan kandungan terenda terdapat pada horizon Bo1 $3,48 \%$, dan pada Si kandungan tertinggi terdapat pada horizon Bo1 9,03\% dan kandungan terendah terdapat pada horizon A 6,37\%.

\section{Saran}

Mengingat adanya variasi terhadap komposisi fraks-fraksi amorf dari $\mathrm{Fe}, \mathrm{Al}$, dan $\mathrm{Si}$ pada beberapa ordo tanah di lahan kering Kabupaten Aceh Besar maka untuk mendapat informasi lanjut penelitian ini perlu dilanjutkan pada lokasi dan ordo tanah yang lain.

\section{DAFTAR PUSTAKA}

Arabia, T. 2009. Karakteristik tanah sawah pada top sekuen berbahan induk volkanik di Daerah Bogor - Jakarta. Disertasi. Program Pascasarjana Institut Pertanian Bogor, Bogor.

Ferdeanty, 2018. Identifikasi morfologi beberapa jenis tanah pada lahan kering di Kabupaten Aceh Besar.

Hardjowigeno, S. 2003. Klasifikasi Tanah dan Pedogenesis. Akademik pressindo, Jakarta. Hal 250.

Holmgren, G.G.S., 1967. A rapid citrate-dithionite extractable iron procedure. Soil Science Society of America Proceedings 31:210-211.

Intan Apriani, 2018. Identifikasi mineral tanah dengan difraksi sinar-X pada beberapa ordo tanah di Aceh Besar.

Soil Survey Staff. 2003. Soil Taxonomy a basic system of soil classification for making and interpreting soil surveys eleventh edition. United States Department of Agriculture. Washington DC.

Soil Survey Staff. 2014. Kunci taksonomi tanah. edisi kedua bahasa indonesia. pusat penelitian tanah dan agroklimat. balai penelitian dan pengembangan pertanian. Institut Pertanian Bogor. Bogor.

Soil Survey Staff. 2014. Keys to soil taxonomy. 10 th ed. USDA-NRCS.Washington, DC.

Sposito, G. 2010. The chemistry of soils. Oxford University Press. New York.

Sufardi, L. Martunis dan Muyassir. 2017. Pertukaran kation pada beberapa jenis tanah di lahan kering Kabupaten Aceh Besar Provinsi Aceh (Indonesia). Prosiding Seminar Pascasarjana (SNP) Unsyiah.Banda Aceh, Indonesia.

Van Reeuwijk, L.P. 1992. Procedures for soil analysis. technical paper, international soil reference and information centre. Wageningen, The Netherlands. 4th ed. p.100. 